\title{
Ethnonationalism and Attitudes Towards Gay and Lesbian Rights in Northern Ireland
}

\author{
Bernadette C. Hayes and John Nagle
}

\begin{abstract}
Disputes over gay and lesbian rights occupy a central place on both national and international agendas in recent years. This is also the case in societies emerging from chronic ethnonational conflict where debates over gay and lesbian rights versus ethnic-based rights predominate. While much scholarly work focuses on the influence of socio-demographic factors in determining attitudes toward gay and lesbian rights in post-conflict societies, to date, the role of political influences, such as ethnonationalism, is noticeably under-researched. It is with this omission in mind that this paper focuses on the influence of ethnonationalism, or congruency in religious, national and communal identity, on attitudes towards gay and lesbian rights issues. Using nationally representative data from Northern Ireland, the results suggest that while ethnonationalism is a key predictor of attitudes among Protestants, it is sociodemographic factors, such as gender, age and educational attainment that are the primary determinants of Catholic views.
\end{abstract}

Keywords: Ethnonationalism, Gay and Lesbian Rights, Post-conflict societies, Religion, Northern Ireland

Word count (minus abstract): 9,490 


\section{Introduction}

Debates over Lesbian Gay Bisexual and Transgender (LGBT) ${ }^{1}$ issues have received increased attention in recent years. This is particularly the case when societies emerging from violent ethnonational conflict are considered. In fact, some scholars go so far as to suggest that because the political settlements reached in such societies prioritize and accommodate the ethnonational dimension of the conflict, violent disputes over sexual citizenship, or the rights of sexual minorities, have now increasingly replaced ethnic divisions as a key source of disagreement within nations emerging from conflict. As a number of commentators note, it is the link between heterosexuality as the dominant group norm and it's taken for granted attribute of the nation that lies at the heart of these divisions (Enloe 2000, Nagel 2003, Mole 2011). Under such circumstances, not only are sexual minorities seen as an alien and polluting influence by the previously sparring ethnic groups to the conflict but their presence is often viewed as threat to the very existence of the nation itself. Thus, not only does ethnonationalism in general reproduce 'heterosexual privilege', but 'heterosexism demonizes and even criminalizes non-reproductive sex' (Peterson, 1999: 55, 47).

Despite the suggested link between ethnonationalism and homophobic views, to date, the impact of ethnonational identity on attitudes towards LGBT rights has not been investigated empirically. The absence of such research must be considered surprising for the following two reasons. First, irrespective of the nature of the division, anti-LGBT and homophobic violence has become a common feature of societies emerging from violent and protracted conflict. Examples, which range from the use of corrective rape against lesbians in apartheid and post-apartheid South Africa to the targeting of gay and lesbian people by resurgent nationalist governments in both Eastern and Central Europe, all attest to the endemic use of violence against sexual minorities within transitional societies (Mole 2011, Kulpa 2013, Thomas et al. 2013). Second, in many cases the very bases of the political settlements facilitate the marginalization and/or targeting of sexual minority groups. This is particularly the case when ethnonationalist conflicts are considered, where the formal recognition of sexual minority rights are often side-lined and down-graded in the interests of the perceived need to accommodate and appease salient ethnonationalist identities (Ashe 2009). 
It is with these considerations in mind that the present study focuses on the influence of ethnonationalism, or congruency in religious, national and communal identity, ${ }^{2}$ on attitudes towards gay and lesbian rights issues in Northern Ireland. ${ }^{3}$ The article proceeds in four stages. First, it discusses the link between ethnonationalism and homophobic views. Second, building on this discussion it outlines the nature of the Northern Ireland Agreement, ${ }^{4}$ particularly in terms of its ethnonationalist foundations as well as the rights of sexual minorities. Third, using nationally representative data from the 2012 Northern Ireland Life and Times Survey, ${ }^{5}$ it then examines the nature and extent of ethnonationalist identity with this society. Finally, it investigates the relationship between ethnonational identity and attitudes towards gay and lesbian rights.

The use of Northern Ireland as a case study to investigate this issue may be considered particularly appropriate in this instance. First, Northern Ireland is a paradigmatic case of a society violently divided by ethnonational groups, British unionists who wish to remain part of the United Kingdom versus Irish nationalists that want the reunification of Ireland. Or, as McGarry and O'Leary (1995: 855), in explaining the Northern Ireland conflict put it: '[it] is fundamentally rooted in ethnonational antagonism'. Second, it is often argued that the dominance of ethnonationalism makes Northern Ireland historically a homophobic society (Conrad 2004, Ashe 2009, Nagle and Clancy 2010, Duggan 2012). In fact, more so than any other factor, it is the acceptance of the assumed link between the heterosexual family and the maintenance of ethnonational identity, a view further reinforced via the intersection of ethnic and religious identity, which many commentators point to as the greatest impediment to the public recognition of and support for sexual minority rights in this society.

\section{Ethnonationalism, Sexuality and Homophobia}

Ethnonationalism is often conceived very broadly and interchangeably with nationalism (Conversi 2002, Coakley 2013). A more parsimonious definition of ethnonationalism focuses on its desire for the territorial boundaries of the state to coincide with the ethnic nation (Hechter 2000). In ethnonationalism, state and nation building fostered a particularistic ethnic identity that reflects the dominant group's power. Within this institutional environment, 'political office holders have incentives to gain legitimacy by favoring co-ethnics or co-nationals over others when 
distributing public goods and government jobs' (Wimmer, Cederman and Min 2013: 321). Since legal and political inclusion within the state is dependent on nationality, ethnonational minorities become structurally problematic and subject to either harsh assimilatory policies or denied their full right to equality (Wimmer 2002).

These societies, characterized by ethnonational conflict, are thus known as 'deeply divided societies' (Horowitz, 1985), places where it is said that 'ethnic identity is strongly felt, behaviour based on ethnicity is normatively sanctioned, and ethnicity is often accompanied by hostility toward outgroups' (Horowitz 1985: 6). A key characteristic of ethnonationalism, therefore, involves a strong emphasis on ethnic exclusivism: privileging and favouring co-ethnics versus outsiders, who are framed as dangers to the group and national purity. Under such circumstances, practically all political and cultural issues are reduced to the position of the ethnic cleavage, identities are cross-indexed by ethnic groupness (Horowitz 1985), and intercommunal boundaries are sharp enough so that 'membership is clear and, with few exceptions, unchangeable' (Lustick 1979: 325). The tendency of ethnonationalist movements to exalt the 'in-group' in opposition to the loathed 'outgroup' is exacerbated in violently divided societies, since the groups not only live alongside each other but also compete in a zero-sum framework for dominance over the polity.

However, as a number of commentators have noted, national self-glorification and Other-defamation also have a moral and sexual dimension (Mosse 1985, Nagel, 2003). National boundaries intersect with sexual ones and these intersections shape prescriptions about what is considered appropriate sexual couplings - specifically, what 'good' women should and should not do, and with whom. Moreover, this seems to be particularly the case in nations that seek to define themselves in ethnic terms, where a sense of belonging is based not only around a belief in a common ancestry, or the principle of a fictive kinship, but also in which the body politic of the nation stands for the family unit (Mole 2011). In fact, feminist scholars have long pointed to the intimate link between heteronormativity and these ethnosexual intersections, particularly in terms of controlling the sexual practices and behaviour of women (Enloe 2000).

As both the reproducers and symbolic representatives of the nation, for ethnonationalists, the control of women's sexuality is paramount and revolves around competing matters of female purity as well as male sexual availability and propriety. As Mosse $(1985: 98,101)$ put it: 'female embodiments of the nation stood for eternal 
forces ... and suggested innocence and chastity' but the right women had to also be available to the right man: 'the maiden with the shield, the spirit that awaits a masculine leader.' However, women's sexuality is also of concern to ethnonationalists in that, as both wives and daughters, they are also the bearers of masculine honour. Moreover, while female fecundity is both valued and encouraged by ethnonationalist movements as a mechanism to ensure the continued existence of the nation, unruly female sexuality, such as lesbianism or sexual relations with the 'enemy', is not only perceived as a threat to the reproductive survival of the nation but is also viewed as dishonouring the nation's men (Mosse 1985, Nagel 1998, 2003).

Concerns about the sexual purity and activities of women, however, are not the only way that sexuality arises as an issue in nationalist discourse. Male heterosexual activity and homosocial male bonding around militaristic masculine virtues, such as honour, patriotism and bravery, are also considered essential for the establishment and survival of the nation (Mosse 1985, Enloe 2000, Nagel 2003). This is particularly the case in divided societies based on ethnonationalist conflict, where a hyper-militarisation of male values, derivative of the many fraternal and militaristic organisations that emerge during the conflict, becomes the norm. These hyper(hetero)masculine identities, however, not only form the basis for acceptable male conduct but also seek to denigrate any attempt to call into question their legitimacy, denouncing them as either non-patriotic (feminism) or a threat to the very survival and reproduction of the nation (sexual dissidents). As Nagel (2003: 160) notes: 'Standards for national conduct that reflect masculinized heteronormativity tend also to be homophobic, and thus are intolerant of sexual diversity, particularly homosexuality'.

Yet, as Jasbir Puar $(2007,2013)$ points out, the assumption that 'the nation is heteronormative and that the queer is inherently an outlaw to the nation-state' is not straightforward. Using the conceptual frame of 'homonationalism' she illustrates 'the complexities of how "acceptance" and "tolerance" for gay and lesbian subjects have become a barometer by which the right to and capacity for national sovereignty is evaluated' (Puar 2013: 336). According to Puar, homonationalism, represents the methods through which some nation-states co-opt lesbian and gay liberal rights discourses as narratives of progress and modernity. In so doing, homonationalism allows states 'to accord some populations access to cultural and legal forms of citizenship at the expense of the partial and full expulsion from those rights of other populations' (Puar 2013: 337). For instance, Puar notes how Israel cynically 
promotes LGBT bodies as representative of Israeli democracy. At the same time, as Israel encourages 'the normalization of some homosexual bodies' (Puar 2013: 338), it utilizes this discourse as part of its 'occupation of Palestine', an authority portrayed by Israel as deeply homophobic and, accordingly, disentitled to self-governance.

Similar concerns have been raised concerning the advancement of lesbian and gay rights in Europe; namely the hijacking of the idea of sexual freedom, specifically the freedom of gay and lesbian people, to promote bigotry against Muslims, immigrants and other minority groups (Butler 2008, Ayoub and Paternotte 2015). And, while scholars disagree as to who are the key proponents advancing such freedoms the top-down role of national governments versus the bottom-up individualistic appeals by gay activists to human rights as part of a European value-based identity all attest to the increasing and divisive influence of gay and lesbian rights both within and external to these nations. As Stychin (1998) has noted, we have seen the emergence over time of LGBT-Europe's 'sexual others', both internally against the Muslim and migrant communities, which are portrayed as more homophobic and thus less European, but also externally against bordering countries such as Russia and Turkey. In fact, some scholars go so far as to suggest that the advancement of gay and lesbian rights is creating new divisions and hierarchies between European nations, namely the perceived morally superior and gay-friendly 'modern West' model, as advocated in established western democracies, versus the backward and 'homophobic East' approach, such as that found in Central and Eastern Europe (CEE), where homosexuality is portrayed as a perversion and foreign import (Ammaturo 2015). Not all scholars, however, agree with this bi-polar and internally homogeneous view of these European nations, particularly in terms of the characterisation of CEE (Colpani and Habed 2014, Moss 2014). For example, whereas some analysts point to the legally precarious position of gay and lesbian people in Italy, despite its status as an established democratic western nation, others reject the unified homophobic characterisation of some CEE nations, pointing, for example, to the greater tolerance of gay and lesbian citizens in Slovenia and to a somewhat lesser extent in Croatia as compared to Serbia. A phenomenon it should be noted that occurs despite the flourishing heteronationalist nature of these Eastern European nations (Moss, 2014).

In summary, sexual depictions of ethnic and national 'us' versus 'others' are the cornerstone by which the ethnic boundaries of nations are constructed, maintained and defended. This is particularly the case in deeply divided societies. As both the 
policing and surveillance of sexual conduct attest, for ethnonationalists the issue of sexualities is a key factor in debates about the very definition of a nation as well as its proposed boundaries and components. As noted above, however, ethnonationalist groups in such societies may also seek to co-opt the language of gay and lesbian rights as a means to advance their own political platforms as liberal and progressive in distinction to their ethnonational rivals, who are framed as conservative and reactionary. Minority ethnonational groups can, furthermore, conflate their own demands for group rights with the struggle of gay and lesbian groupings. This is also the case in Northern Ireland, where despite their differing ethnonational identities and territorial aspirations, ethnonationalist discourses have long reflected and in some cases reified this ethnosexual division. However, as in other European nations, ethnic minority groups within this society, have also attempted to conflate their ethnonationalist aspirations with demands for gay and lesbian rights as evidenced not only in their increasing adoption of human rights discourses but also the support of nationalist politicians for the sexual minority rights of the LGBT community.

\section{Ethnonationalism, Sexual Minority Rights and the Agreement}

Signed in April 1998, the Northern Ireland Agreement was a result of negotiations aimed at ending three decades of conflict which resulted in the deaths of more than 3,500 people, the vast majority of which were members of the civilian population (Hayes and McAllister 2013). Based on a consociational model of conflict regulation and the 'principle of parity in esteem', a key assumption of the Agreement was that entrenched communal divisions could be accommodated and eventually ameliorated through institutionalized power-sharing arrangements. These institutionalized powersharing arrangements included: the formation of a Northern Ireland Assembly with devolved legislative powers; the creation of a 'power-sharing' Northern Ireland Executive, headed by a premiership diarchy (a first minister and deputy first minister possessing equal powers) and using the D'Hondt method to allocate ministers proportionately to the main parties; ${ }^{6}$ and the introduction of the cross-community support principle for any major decisions taken by the Assembly. ${ }^{7}$ In fact, more so than any other factor, critics of consociationalism argue that it was this legislative requirement of cross-community support for major decisions and its accompanying system of mutual vetoes which has not legitimized ethnonational division but has also led to the carve up of electoral politics along communal lines (Taylor 2009: 320). As 
Racioppi and See (2006: 203) put it: one of the main weaknesses of consociationalism lies precisely in the fact that it reinforces the 'ethnic basis of politics' and encourages 'ethnic outbidding by parties ... to advance their [own] ethnic group interests and agendas'.

Although the Agreement was primarily designed as a mechanism to manage, and eventually alleviate ethnonational conflict, provisions were also made to supposedly safeguard those members of society that subscribed to identities outside of the ethnonational framework. In particular, a section in the Agreement on Human Rights stated that public authorities in Northern Ireland would 'promote equality of opportunity in relation to religion and political opinion; gender; race; disability; age; marital status; dependants; and sexual orientation (Northern Ireland Office 1998: 20). Overseen and monitored by a newly established and independent public body - the Equality Commission for Northern Ireland - this statutory obligation on public authorities was subsequently implemented under Section 75 of the 1998 Northern Ireland Act. Under this legislation, not only were public authorities legally obliged to promote 'good practice and due regard' for all minority groups in Northern Ireland, including sexual minority groups, but also to involve them in consultation processes. As a result of this legislative activity, sexual minority communities in Northern Ireland are now officially designated as stakeholders in social and political initiatives and a number of laws have been introduced to protect their rights. ${ }^{8}$

Despite these legislative activities, alongside the commitment to sexual minority rights enshrined in the Agreement, there is evidence to suggest that homophobic attacks and sentiment have, albeit with some fluctuation, not only increased markedly since the Agreement, but this is particularly the case for those of a violent nature that are directed primarily against gay men (Jarman and Tennant 2003, Duggan 2012). For example, in 2013, there were 246 homophobic incidences reported to the Police Service in Northern Ireland (PSNI), the highest number of incidents recorded and 26 more than its previous peak of 220 in 2006. In addition, there were 149 homophobic crimes, 103 of which involved a victim-based crime, involving violence with (50) or without (53) injury. ${ }^{9}$ This was again slightly more than the previous peak of 95 reported victim-based attacks in 2006, 46 of which involved violence with injury (see PSNI 2013). Survey research on the lesbian, gay and bisexual community replicates these findings. For example, Jarman and Tennant (2003: 65), in the most recent investigation of this issue, not only found that the 
percentage of lesbian/gay/bisexual people that had experienced violence was 'higher' than in Great Britain and Ireland, but there was also a 'greater use of violence as well as a greater propensity to use violence in such attacks' than in the past.

Homophobia is also evident in the actions and policies of some of Northern Ireland's elected politicians. Notably, post-Agreement politics in Northern Ireland has witnessed the electoral triumph of the so-called 'hardline' ethnonationalist parties Sinn Féin and the Democratic Unionist Party (DUP) - which have also taken contrasting positions on sexual minority issues and rights. Sinn Féin, the dominant Irish nationalist party, has sought to support sexual minority rights, namely by conflating their struggle as a minority movement struggle. As Moving On, Sinn Féin's (2013) 'Policy for Lesbian, Gay and Bi-Sexual Equality,' frames it: ...'[nationalists] are only too well aware of what it means to be treated as second-class citizens. Our politics are the results of decades of resistance to marginalisation and discrimination.' This is not to deny, however, the traditional reluctance of some politicians even within the nationalist community to actively pursue such rights for fear of alienating their more conservative constituency members (Conrad 2004).

The DUP, by contrast, have adopted an extremely negative stance in relation to the LGBT population so much so that some commentators have accused it of having a 'near pathological obsession with homosexuality' (McDonald 2005). For example, not only have a number of DUP politicians, such as Iris Robinson, publicly denounced homosexuality as an 'abomination' which made her 'feel sick' (see Ashe 2009), but they have also used their position as a leading partner in the power-sharing government to impede equality legislation for the gay and lesbian population. As recently as June 2013, for example, the DUP used its power of veto to block the legalisation of same-sex marriage in Northern Ireland. By triggering a petition of concern - such that a motion can only pass if a majority of nationalists and unionists support it - not only did the DUP exercise the 'communal' veto to block legislation designed to further equality for a non-ethnonational grouping, in this case sexual minorities, but, in doing so, they ironically used a mechanism designed to stop majoritarian ethnonational policies. ${ }^{10}$ Even more recently and in response to a row over a pro-gay marriage cake, the DUP, via a private members bill tabled in December 2014, is seeking to introduce a conscious clause into equality legislation the Northern Ireland Freedom of Conscious Amendment Bill - which proposes a legal 
exemption for individuals and businesses on grounds of strongly held religious views. ${ }^{11}$

While the differing positions adopted by the two main parties in relation to sexual minority issues may be due in part to the religiously strong fundamentalist tradition among certain DUP members ${ }^{12}$ and their perceptions concerning the voluntary, or non-biological, nature of homosexuality, ${ }^{13}$ they also reflect their opposing views of the Agreement's minority rights legislation. For Irish nationalists, the minority ethnonational group within Northern Ireland, the Agreement is viewed as a mechanism to redress a number of imbalances and grievances, especially in relation to the accommodation of nationalists in the polity and the recognition of their cultural identities in the public sphere (Tonge 2004). However, unionists have dismissed this approach as nothing more than a nationalist plot to further their own interests. Pointing instead to an anti-Unionist stance as evidenced via the introduction of legislation and the establishment of Commissions to curb unionist symbols and expressions of culture, ${ }^{14}$ not only do many unionistsview such practices as overtly discriminatory against their community, but also as a blatant attack on their British identity and associated cultural symbols and heritage (see McAuley and Tonge 2010).

In summary, there is now a growing body of evidence to suggest that Northern Ireland remains a deeply homophobic society. Despite the enshrinement of sexual minority rights in the Agreement as well as the various legislative initiatives since then, there is empirical evidence to suggest that not only have homophobic attacks and sentiments markedly increased since its ratification in 1998 but this is particularly so when violent attacks, especially those directed against gay men, are considered. To what extent, as a number of commentators have suggested, are these homophobic acts and sentiments linked to the increasing legitimisation and entrenchment of ethnonationalist identity within this society? It is to an empirical investigation of this question - the relationship between ethnonationalist identity and gay and lesbian rights - that we now turn.

\section{Ethnonationalism and Gay and Lesbian Rights}

As noted earlier, the conflict in Northern Ireland was viewed as a long-standing dispute over two contested ethnonational identities, British-unionism versus Irishnationalism. And, while religious identity served as an important boundary-marker in identifying the protagonists, the conflict could not be reduced to religious terms. This 
is not to suggest, however, that the conflict was totally bipolar in nature. As previous research has shown, both within and between these two opposing ethnonationalist traditions, there are also important intra-religious differences in terms of national and communal identity (see Fahey et al 2006, Coakley 2007, Hayes and McAllister 2013). For example, not all Protestants perceived themselves as British and/or adopt a unionist label. Similarly, neither did all Catholics view themselves as Irish and/or choose a nationalist label. In Northern Ireland, religious affiliation, national identity and communal affiliation, including territorial allegiance, were intertwined in a complex way that not only provided the basis for the conflict but, until recently, also reinforced it violent and recurring nature.

Recent research lends support to these earlier findings. As the data in Table 1 demonstrates clearly, although national identity and communal affiliation significantly overlap in both religious communities, they are by no means coterminous. ${ }^{15}$ For example, while around seven out of every ten Protestants see themselves as British and around six out of ten adopt a unionist label, only 45 per cent are willing to choose both identities and regard themselves as British and unionist. These results are replicated when the Catholic population are considered. Here, whereas around seven out of every ten Catholics see themselves as Irish and exactly half are willing to adopt a nationalist label, only a notable minority - around two-fifths in this instance - are willing to describe themselves as both Irish and Nationalist. Thus, for both religious communities, there is evidence to suggest that although there is a strong reinforcement between national identity and communal affiliation, they are not interchangeable. To what extent, however, does this unity in ethnonational self-identification lead to homophobic views? In other words, as suggested earlier, are individuals who endorse an ethnonationalist label - those willing to perceive themselves as either both British and unionist or both Irish and nationalist - significantly more likely to adopt a negative stance towards gay and lesbian issues than those who do not?

\section{[Insert Table 1 about here]}

Table 2 addresses this question by focusing on the relationship between congruency in both national and communal identity and attitudes towards same-sex marriage and the teaching of gay and lesbian rights in schools. The results are clear. 
Irrespective of whether same-sex marriage or the teaching of gay and lesbian rights in schools are considered, it is those who are congruent in their ethnonational identity see themselves as either British-unionist or Irish-nationalist - who stand out as the most negative in their views. This in not to deny, however, some marked religious differences in attitudes in this instance, with Protestants being notably more likely to adopt a negative stance in relation to both these issues than Catholics.

Focusing initially on same-sex marriage, while just under half, or 46 per cent, of all respondents with an overlapping national and communal identity perceived such marriages as invalid, a significantly lower proportion of respondents who did not conform to this dual-identity label - just under a third in this instance - endorsed this view. A similar, albeit converse, pattern emerges when the validity of such marriages are considered; while just over half of all respondents who expressed a congruent position in relation to identity endorsed this view, the equivalent proportion among those who did not was fifteen percentage points higher at 69 per cent.

\section{[Insert Table 2 about here]}

These patterns are replicated when members of the two main religious communities - Protestants and Catholics - are considered separately. Among Protestants who viewed themselves as both British and unionist, around three-fifths, or 61 per cent, rejected such marriages as invalid. By contrast, among those who did not express such a dual-identity position the equivalent proportion was notably lower at just 42 per cent. Similar, albeit much less marked, divisions emerge when the Catholic community is considered, with Catholics who expressed a congruency in identity being notably more likely to view such marriages as invalid that those who did not; 30 per cent as compared to 22 per cent in this instance. This is not to discount, however, the marked differences in attitudes between the two main religious communities - Protestant and Catholic - in relation to this issue. Irrespective of whether or not congruency in identity preferences are considered, in both cases, Protestants are around twice as likely to adopt a negative stance in relation to this issue as Catholics.

These findings are repeated when attitudes towards the teaching of gay and lesbian rights in schools are considered. Again, it is those who are willing to endorse 
an ethnonationalist label that emerge as the most negative in viewpoint. For example, whereas two-thirds of Protestants who endorsed such a label - a British-unionist identity - rejected the teaching of equality rights for gays and lesbians in schools, the equivalent proportion among those who did express this dual identity was markedly lower at 49 per cent. Divisions, albeit less marked, also occur when the Catholic community is considered, with those who expressed a congruency in identity being the most negative in their views. Again, this is not to discount the notable religious differences in opinion regarding this issue, with Protestants being significantly more likely to adopt a negative stance than Catholics.

Multivariate analysis lends some further, albeit partial, support to these findings. Even when a range of background factors are included in the analysis, ethnonationalism, or congruency in national and communal identity, emerges as a significant predictor of attitudes, albeit solely among Protestants (see Tables 3 and 4). Irrespective of whether attitudes towards the validity of same-sex marriage or the teaching of gay and lesbian rights in schools is considered, it is individuals within the Protestant community, who perceive themselves as both British and unionist, who emerge as the most negative in their views. This is not the case, however, among the Catholic community where socio-demographic background, and not ethnonational identity, emerges as a significant predictor of attitudes.

Focusing initially on attitudes towards same-sex marriages, the results in Table 3 are clear. Even when a range of socio-political factors are included in the analysis, ethnonationalism emerges as a significant predictor of views among Protestants. Protestants that see themselves as both British and unionist are significantly more likely to view such marriages as invalid than those who do not. This is not to suggest, however, that ethnonationalism is the sole predictor of attitudes among Protestants in this instance. Other noteworthy determinants include the positive effects of gender, church attendance, and age. Males, regular church attenders, and older individuals are significantly more likely to hold a more negative view of such marriages than either females, irregular church attenders, or the young. For Catholics, by contrast, it is socio-demographic factors, and not ethnonationalism, that emerged as the key predictor of views. Males, older individuals, as well as the lesser educated are significantly more likely to consider such marriages as invalid in comparison to females, the young, or the well-educated. 
[Insert Table 3 about here]

These results are repeated when attitudes towards the teaching of equality for gay and lesbians in schools are considered (see Table 4). While both ethnonationalism and socio-demographic background stand out as a significant predictor of attitudes among Protestants, this is not the case among Catholics where it is again sociodemographic background that emerges as the sole predictor of opinion in this instance. As in our earlier analysis, not only are Protestants who see themselves as both British and unionist significantly more likely to reject the teaching of equality rights for gays and lesbians in schools, but this is also the case among regular church attenders and those with no educational qualification. Among Catholics, it is again socio-demographic factors, such as gender, age and educational attainment, which emerge as the key predictor of views.

[Insert Table 4 about here]

In summary, then, the results are clear. While ethnonational identity and to a lesser extent socio-demographic background are key predictors of attitudes among Protestants, it is socio-demographic background, and not ethnonationalism, which emerges as the key determinant of Catholic views. Thus, at least as far as the suggested negative relationship between ethnonationalism and support for gay and lesbian rights are concerned, the key finding of this analysis is that the influence of ethnonationalism remains an exclusively Protestant phenomenon. Only within the Protestant community do individuals who are congruent in their ethnonational identity - see themselves as British-unionist - adopt a significantly more negative stance in relation to same-sex marriage and the teaching of gay and lesbian rights in schools than those who are not. What may explain this exclusively Protestant finding? It is to an investigation of this, our final issue, that we now turn.

\section{Explaining the Influence of Ethnonationalism on Protestant Views}

As noted earlier, homophobic attitudes have a long and deep-seated tradition in Northern Ireland, and this appears to be particularly the case when views among the Protestant community are considered. Previous research has shown consistently that not only do Protestants hold more negative views about homosexuality and gay and 
lesbian rights than Catholics, but this is also the case when views of their political leaders, particularly within the DUP, or the most 'hardline' ethnonationalist party within the unionist community, are considered (Duggan 2012). For example, not only was the campaign to 'Save Ulster from Sodomy' led by the then DUP leader, Ian Paisley, but since then a number of DUP members have been similarly quite open about their aversion to homosexuality, most notably on religious grounds. ${ }^{16}$ Moreover, as noted earlier, there is also evidence to suggest that these homophobic views are reinforced by perceptions concerning the voluntary, or non-genetic, nature of homosexuality. However, this antipathy towards homosexuality and gay and lesbian rights among the Protestant community and their political leaders is not just derivative of biblical discourses and attributions concerning the origins of sexuality. Rather a key additional determinant in accounting for unionist opposition to gay and lesbian rights is also their general hostility to equality legislation for gay and lesbian people, a phenomenon which is again most marked among members of the DUP, many of whom have traditionally belonged to the Evangelical Christian tradition. It is these two factors - their general antipathy towards homosexuality as well as their rejection of equality rights for gay and lesbian people - which we suggest explain the link between ethnonationalism and homophobic attitudes within the Protestant community.

The results in Table 5 support this explanation. Irrespective of whether contact with gay and lesbian people, perceptions of the origins of homosexuality, or general attitudes towards equality rights for gay and lesbian people are considered, Protestants that perceive themselves as both British and unionist are significantly more likely to adopt a negative stance in relation to these issues than those who do not. For example, whereas just over two-fifths of Protestants with an overlapping national and communal identity claimed to have had no contact with members of the gay or lesbian community, the equivalent proportion among those who rejected this dual identity was markedly lower at just 27 per cent. Similar differences emerge when the source of homosexual orientation or attitudes towards the equality rights of gay and lesbian people are considered. It is again Protestants who are congruent in both their national and communal identity that emerge as the most negative or homophobic in their views.

[Insert Table 5 about here] 
To what extent does their more negative stance in relation to these same-sex issues explain our previously demonstrated link between congruency in ethnonationalism and negative attitudes towards same-sex marriage and the teaching of gay and lesbian rights in schools? Tables 6 and 7 address this question by undertaking a series of regression equations in which both ethnonationalism as well as our proposed explanation - general antipathy towards homosexuality and attitudes towards the equality rights of gay and lesbian people - are included in the analysis. Three models are shown: Model 1 which shows the effect of ethnonationalism on attitudes towards same-sex marriage and the teaching of gay and lesbian equality issues in schools; Model 2 which controls for a range of potentially confounding variables such as socio-demographic background and party support; Model 3 which includes the additional effects of our general explanation (namely the lack of contact with gay and lesbian people, perceptions concerning the voluntary nature of homosexuality, a negative stance towards the equality rights of gay and lesbian people).

Overall the results lend much support to our hypothesis that it is antipathy towards homosexuality and the equality rights of gay and lesbian people that is the primary factor in explaining attitudes towards same-sex marriage and the teaching of equality rights for gay and lesbian people in schools. As the data in Tables 6 and 7 demonstrate clearly, although ethnonational identity has a statistically significant effect on attitudes towards both these issues (see model 1), an effect that remains even when a range of control variables are included in the regression equation (see model 2 ), this statistically significant difference disappears once our proposed explanation is included in the analysis (see model 3). In other words, it is antipathy towards homosexuality and the equality rights of gay and lesbian people that is the primary factor in accounting for the impact of ethnonationalism on attitudes towards same-sex marriage and the teaching of equality rights in schools.

[Insert Tables 6 and 7 about here]

Of these various determinants, however, it is that attitudes towards equality rights for gay and lesbian people which emerges as the key predictor in accounting for views. In both cases, the results are statistically significant and in the direction expected: Protestants who adopt a negative stance in relation to this issue are also 
significantly more likely to view same sex marriage as invalid and also to reject the teaching of equality rights for gay and lesbian people in schools. Thus, and in partial support of the homonationalism thesis, a key finding of this analysis is the possible conflation of gay and ethnic minority rights among Protestants, or in this instance, the perception of a positive link between the rights of gay and lesbian people and that of the minority nationalist community. This is not to suggest, however, that attitudes towards equality legislation for gays and lesbians are the sole determinant of views in this instance. Other notably, albeit less consistent, determinants includes the significant positive effect of perceptions concerning the voluntary origins of homosexuality on attitudes towards same-sex marriages. As in previous international research (Haider-Markel 2008), individuals who perceive homosexuality as a matter of choice - as compared to those who believe it is biologically determined - are also notably more likely to adopt a negative stance in relation to this issue than those who do not. Finally, at least as far as opinions on same-sex marriage are concerned, there is also some evidence to suggest that, even when attitudes towards a range of samesex issues are included in the analysis, socio-demographic background remains an additional and significant determinant of Protestant views. Replicating our earlier analysis, it is again men, regular church attenders and older individuals who stand out as the most negative in their views

\section{Conclusion}

In recent years, explorations of the relationship between gender, nationalism and warfare have gained increasing momentum, particularly within feminist scholarship. There is now a considerable body of work to suggest that not only is nationalism and ethnonationalism profusely patriarchal but it is also deeply embedded within a heteronormative framework. Even as a number of nation-states adopt the rhetoric of 'homonationalism', such narratives merely act as inclusionary and exclusionary devices to signify which sections of the population should be accorded membership of the nation. Moreover, there is some evidence to suggest that this is particularly the case in societies emerging from violent and deeply-seated conflict based on ethnonational lines. As noted earlier, in such societies not only do national boundaries intersect with sexual ones but these intersections both dictate and determine what is considered appropriate sexual couplings. More so than any other issue, it is this factor - the intimate link between ethnonationalism and heteronormativity - which many 
commentators point to as not only the root cause of an increase in the frequency and intensity of violence against sexual minorities in such societies but also in the escalation in levels of public antipathy towards the rights of LGBT people more generally.

The results of this study, however, lend only partial support to this hypothesis, or the assumed link between ethnonational identity and a homophobic stance in relation to gay and lesbian rights in societies emerging from deeply-seated ethnonational conflict. Irrespective of whether attitudes towards the validity of samesex marriage or the teaching of gay and lesbian rights in schools are considered, although ethnonational identity is a key predictor of attitudes among Protestants, it is socio-demographic background, and not ethnonationalism, which emerges as the key determinant of Catholic views. Thus, at least as far as negative attitudes towards gay and lesbian rights in Northern Ireland are concerned, the influence of ethnonationalism is an exclusively Protestant phenomenon.

What may explain these religious differences in findings? Part of an explanation we suggest rests with the long-standing and greater attachment to ethnonationalist identity within the Protestant community as compared to their Catholic counterparts. As recent research elsewhere demonstrates, while being British and unionist has been a consistent preference for a majority of Protestants over the last two decades, this is not the case among the Catholic community where the proportion of Catholics who endorse an ethnonationalist label - see themselves as both Irish and nationalist - has fluctuated considerably over the same period; rising from its lowest point of just 31 per cent in 1989 to a high point of 55 per cent in 1999, or just after the 1998 Agreement, but subsequently falling back to a minority position of just 43 per cent by 2010 (see Hayes and McAllister 2013: 68). It is this factortheir greater and more long-standing attachment to an ethnonationalist identity which we suggest may explain the exclusive impact of ethnonationalism on attitudes toward gay and lesbian rights within the Protestant community.

This is not to discount, however, the mediating impact of attitudes towards a range of same-sex issues on the relationship between ethnonational identity and attitudes towards gay and lesbian rights within the Protestant community. As the results also show, once opinions on a range of same-sex issues are included in the analysis, the influence of ethnonationalist identity is reduced to insignificance. Of these various issues, however, it is that attitudes towards equality rights for gay and 
lesbian people which emerges as the key predictor in accounting for views.

Protestants who adopt a negative stance in relation to this issue are also significantly more likely to view same sex marriage as invalid and also to reject the teaching of equality rights for gay and lesbian people in schools. As previously suggested, one possible explanation for this finding is the homonationalism thesis, or the possible conflation of gay and lesbian rights issues with ethnic minority rights issues for the nationalist community. As discussed earlier, for many unionists not only was the inclusion of minority rights legislation in the Agreement viewed as a nationalist plot to further their interests at their expense but it was also perceived as deeply damaging to the rights of the Protestant community in terms of a blatant attack on their British identity and cultural heritage.

It is to an investigation of this issue - the possible conflation of ethnic minority rights issues with other minority rights - among both majority and minority ethnic groupings that future research should be directed. Such research should focus on the rights of a range of minority groups, such as women's rights as well as the rights of other minority identity groups outside the dominant ethnic cleavage. Moreover, where possible, the research should be cross-national and comprehensive in focus, investigating the impact of ethnonationalism on these issues across a range of transitional societies emerging from violent and deep-seated ethnonationalist conflict.

\section{Endnotes}

1 Given its dominance in the research literature and associated legislative and policy initiatives, we use the term LGTB rather than LGBTQ or LGBTQI, 
although it should be noted that debates about bisexual and transgender concerns have received much less attention than those related to lesbian and gay rights.

2 Alternative analysis which also included congruency in territorial preferences gave rise to identical substantive findings.

3 Because of the absence of survey data on views concerning the rights of bisexual and transgendered people, only attitudes towards gay men and lesbian women are investigated in the analysis.

Symbols and labels represent the most visible manifestation of the Northern Ireland conflict. Thus, to avoid any religious overtones and to adopt the least contentious label, we use the term Northern Ireland Agreement rather than the 'Belfast Agreement' or 'Good Friday Agreement'.

The 2012 Northern Ireland Life and Times Survey is a nationally representative survey of 1,204 adults aged 18 or over conducted between $1^{\text {st }}$ October 2012 and $10^{\text {th }}$ January 2013. Using face-to-face interviews and with a response rate of 57 per cent, the survey was based on a systematic random sample of addresses selected from the Postal Address File (PAF) database, the most up-to-date and complete listing of addresses in Northern Ireland.

6 Under the terms of the 1998 Agreement, the co-premiers who head the Executive - the first minister and deputy first minister - had to secure the support of both a majority of nationalists and unionists, as well as a majority in the Assembly as a whole. Since the St Andrews Agreement of 2006, they are now appointed by the leaders of the largest party and the second largest party in the opposite designation. The remaining ministers are chosen by the nominating officers of each party.

$7 \quad$ To permit the latter, the Agreement requires that members elected to the Assembly designate themselves as 'nationalist, unionists, and others', and no member can change their designation more than once during an Assembly session.

8 These include: the Employment Equality (Sexual Orientation) Regulations (Northern Ireland) 2003; the Civil Partnership Act 2004; and the Equality Act (Sexual Orientation) Regulations (Northern Ireland) 2006.

While the PSNI (Police Services of Northern Ireland) began recording homophobic incidents in 2000, it was not until 2004 that they began separately recording homophobic crimes (see http://www.psni.police.uk). 
10 This was the third time that the DUP used a 'petition of concern' to veto the legalisation of same-sex marriage in Northern Ireland. Both in October 2012 and April 2013, the DUP also used this mechanism to narrowly defeat a Sinn Féin-backed motion to allow same-sex couples to marry. Currently, Northern Ireland is the only region within the United Kingdom that has not introduced legislation to permit same-sex marriage.

11 The DUP's proposed 'Freedom of Conscience Amendment Bill' was a reaction to Northern Ireland's Equality Commission supporting a gay rights activist in a court case against a Christian-owned bakery that refused on religious grounds to make a cake with a pro-gay marriage slogan. Sinn Féin has stated that they will block the bill should it be voted on in the assembly.

12 See Mitchell and Tully (2004).

13 A view epitomised by Iris Robinson when she stated that homosexuality was not only an illness but that it could be cured by therapy (see Ashe 2009).

14 A key exemplar of which remains the ongoing dispute between the Orange Order and the Parades Commission as well as the continuing controversy over the decision by Belfast council in December 2012 to limit the amount of days that the Union flag will fly over Belfast City Hall.

15 For the purpose of this investigation and in common with previous research in this area, national identity refers to an identification with labels such as 'British' and 'Irish'. Following the work of Coakley (2007), we refer to whether an individual identifies as being 'unionist' or 'nationalist' as communal identity, otherwise known as political identity in much of the literature.

16 A position also expressed by Peter Robinson (2008), the First Minister of Northern Ireland, when in defending his wife's homophobic views, stated: 'It wasn't Iris Robinson who determined that homosexuality was an abomination, it is the Almighty.' 


\section{References}

Ammaturo, F. R. 2015. 'The "Pink Agenda": Questioning and Challenging European Homonationalist Sexual Citizenship', Sociology : 1-16.

Ashe, F. 2009. 'Iris Robinson's Excitable Speech: Sexuality and Conflict Transformation in Northern Ireland', Politics 29, 1: 20-27.

Ayoub, P.M. and Paternotte, D. 2014. 'Introduction' in P.M. Ayoub and D. Paternotte (eds.), LGBT Activism and the Making of Europe. Basingstoke: Palgrave Macmillan, pp. 1-25.

Butler, J. 2008. 'Sexual politics, torture, and secular time', British Journal of Sociology 59, 1: 1-23.

Coakley, J. 2007. 'National Identity in Northern Ireland? Stability or Change?' Nations and Nationalism 13, 4: 573-597.

Coakley, J. 2013. Nationalism, Ethnicity and the State. London: Sage.

Colpana, G. and Habed, A.J. 2014. "'In Europe It's Different": Homonationalism and Peripheral Desires in Europe' in P.M. Ayoub and D. Paternotte (eds.), LGBT Activism and the Making of Europe. Basingstoke: Palgrave Macmillan, pp 7393.

Conrad, K. 2004. Locked in the Family Cell: Sexuality, and Political Agency in Irish National Discourse. Wisconsin: University of Wisconsin Press.

Conversi, D. 2002. 'Conceptualizing Nationalism: An Introduction to Walker Connor's Work' in D. Conversi (ed.), Ethnonationalism in the Contemporary World: Walker Connor and the Study of Nationalism. London: Routledge, pp.123.

Duggan, M. 2012. Queering Conflict: Explaining Lesbian and Gay Experiences of Homophobia in Northern Ireland. Farnham: Ashgate.

Enloe, C. 2000. Bananas, Beaches and Bases: Making Feminist Sense of International Politics. Berkeley: University of California Press.

Fahey, T., Hayes, B.C., and Sinnott, R. 2006. Conflict and Consensus: A Study of Values and Attitudes in the Republic of Ireland and Northern Ireland. Leiden: Brill.

Haider-Markel, D. P. and Joslyn, M.R. 2008. 'Beliefs About the Origins of Homosexuality and Support for Gay Rights', Public Opinion Quarterly 72, 2: 291-310.

Hayes, B.C. and McAllister, I. 2013. Conflict to Peace: Politics and Society in Northern Ireland Over Half a Century. Manchester: Manchester University Press.

Horowitz, D. 1985. Ethnic Groups in Conflict. California: University of California Press.

Jarman, N. and Tennant, A. 2003. An Acceptable Prejudice? Homophobic Violence and Harassment in Northern Ireland. Belfast: Institute for Conflict Research.

Kulpa, R. 2013. 'Western Leveraged Pedagogy of Central and Eastern Europe: Discourses of Homophobia, Tolerance, and Nationhood', Gender, Place \& Culture: A Journal of Feminist Geography 1-18. 
Lustick, I. 1979. 'Stability in Deeply Divided Countries: Consociationalism versus Control', World Politics 31, 3: 325-44.

McAuley, J.W. and Tonge, J. 2010. 'Britishness (and Irishness) in Northern Ireland Since the Good Friday Agreement', Parliamentary Affairs 63, 2: 266-85.

McGarry, J. and O’Leary, B. 1995. Explaining Northern Ireland: Broken Images. Oxford: Wiley-Blackwell.

Mitchell, C. and Tully, J. 2004. 'The Moral Minority: Evangelical Protestants in Northern Ireland and Their Political Behaviour', Political Studies 52, 3: 585602.

Mole, R. 2011. 'Nationality and Sexuality: Homophobic Discourse and the "National Threat" in Contemporary Latvia', Nations and Nationalism 17, 3: 540-60.

Moss, K. 2014. 'Split Europe: Homonationalism and Homophobia in Croatia' in P.M. Ayoub and D. Paternotte (eds.), LGBT Activism and the Making of Europe. Basingstoke: Palgrave Macmillan, pp. 212-232.

Mosse, G. L. 1985. Nationalism and Sexuality: Middle-Class Morality and Sexual Norms in Modern Europe. Madison, WI: University of Wisconsin Press.

Nagel, J. 1998. 'Masculinity and Nationalism: Gender and Sexuality in the Making of Nations', Ethnic and Racial Studies 21, 2: 242-269.

Nagel, J. 2003. Race, Ethnicity and Sexuality: Intimate Intersections, Forbidden Frontiers. Oxford: Oxford University Press.

Nagle, J. and Clancy, M.C. 2010. Shared Society or Benign Apartheid? Understanding Peace-Building in Divided Societies. Basingstoke: Palgrave Macmillan.

Northern Ireland Office.1998. Agreement Reached in the Multi-Party Negotiations (Belfast: HMSO).

Puar. J. 2007. Terrorist Assemblages: Homonationalism in Queer Times. Durham: Duke University Press.

Puar. J. 2013. 'Rethinking Homonationalism', International Journal of Middle East Studies 45: 336-339.

Peterson, V.S. 1999. 'Sexing Political Identities/Nationalism as Heterosexism', International Journal of Feminist Politics 1, 1: 34-65.

PSNI. 2013. Trends in Hate Motivated Incidents and Crimes Recorded by the Police in Northern Ireland 2004/05-2012/13. Belfast: PSNI.

Racioppi, L. and O'Sullivan See, K. 2006. 'Engendering Democratic Transition from Conflict: Women's Inclusion in Northern Ireland's Peace Process', Comparative Politics 38, 2: 189-208.

Sinn Féin. 2013. 'Moving On - A Policy for Lesbian, Gay and Bi-Sexual Equality', http://www.sinnfein.ie/contents/16522 (Accessed 7 January 2014).

Stychin, C. 1998, A Nation of Rights: National Cultures, Sexual Identity Politics, and the Discourse of Rights. Philadelphia, PA: Temple University Press.

Taylor, R. 2009. 'The Injustice of a Consociational Solution to the Northern Ireland Problem' in Rupert Taylor (ed.), Consociational Theory: McGarry and O'Leary and the Northern Ireland Conflict. London: Routledge, pp. 309-329. 
Thomas, K., Masinjila, M. and Bere, E. 2013. 'Political Transition and Sexual and Gender-Based Violence in South Africa, Kenya, and Zimbabwe: A Comparative Analysis', Gender \& Development 21, 3: 519-532.

Tonge, J. 2004. The New Northern Irish Politics. Basingstoke: Palgrave Macmillan.

Wimmer, A, Cederman, L.E. and Min, B. 2009. 'Ethnic Politics and Armed Conflict: A Configurational Analysis of a New Global Dataset', American Sociological Review 74, 2: 316-337

Wimmer, A. 2002. Nationalist Exclusion and Ethnic Conflicts: Shadows of Modernity. Cambridge: Cambridge University Press. 
Table 1: Religious Denomination and Identity Preferences

\begin{tabular}{lcc}
\hline & \multicolumn{2}{c}{ (Percentages) } \\
& Protestant & Catholic \\
\hline $\begin{array}{l}\text { National Identity: } \\
\text { British/Irish }\end{array}$ & 68.4 & 67.8 \\
$\begin{array}{l}\text { Communal Identity: } \\
\text { Unionist/Nationalist }\end{array}$ & 61.7 & \\
$\begin{array}{l}\text { Congruency in Identity: } \\
\text { British-Unionist/Irish-Nationalist }\end{array}$ & 44.8 & 50.3 \\
[Base N] & {$[489]$} & 41.2 \\
\hline
\end{tabular}

The questions were: 'Which of these best describes the way you think of yourself?' Response categories were British, Irish, Ulster, Northern Irish or Other; 'Generally speaking do you consider yourself as a unionist, a nationalist or neither.'

Source: Northern Ireland Life and Times Survey, 2012. 
Table 2: Congruency in Identity and Attitudes Towards Gay Rights

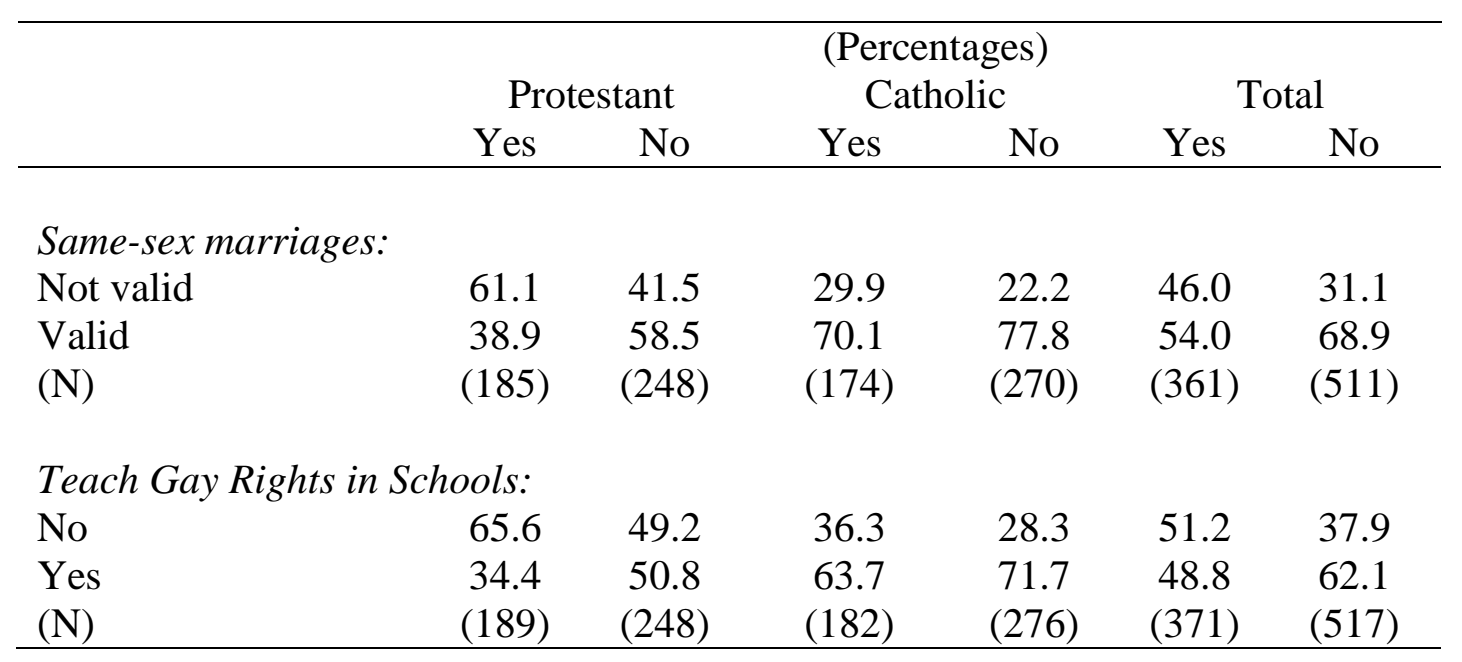

The questions were: 'Do you think marriages between same-sex couples should or should not be recognized by the law as valid, with the same rights as traditional marriages?; 'At the moment schools in Northern Ireland are required to teach children about equality among groups in society, for example equality between different religions and different ethnic groups. Do you think that schools should have to teach about equality for gay men and lesbians with other groups in society?'

Source: Northern Ireland Life and Times Survey, 2012. 
Table 3: Effect of Ethnonationalism on Attitudes Towards Same-Sex Marriages

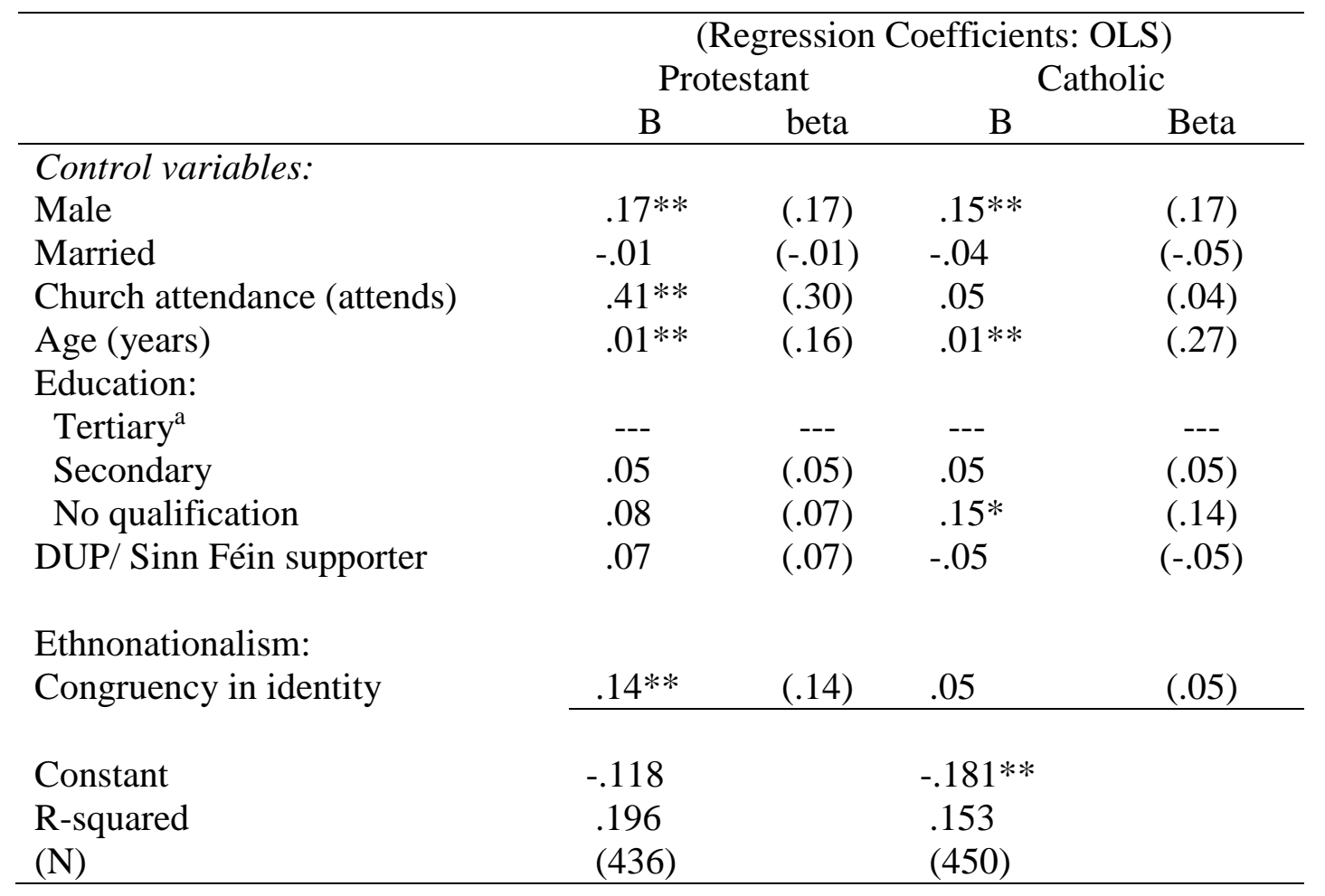

Notes: Attitudes towards same-sex marriages are coded 0 (valid) and 1 (invalid); *, significant at the 0.05 level; **, significant at the 0.01 level; ${ }^{\text {a }}$, missing category of comparison; Alternative analysis based on a logistic regression model gave rise to identical substantive conclusions.

Source: Northern Ireland Life and Times Survey, 2012. 
Table 4: Effect of Ethnonationalism on Attitudes Towards Teaching Gay Rights in Schools

\begin{tabular}{|c|c|c|c|c|}
\hline & \multicolumn{4}{|c|}{ (Regression Coefficients: OLS) } \\
\hline & \multicolumn{2}{|c|}{ Protestant } & \multicolumn{2}{|c|}{ Catholic } \\
\hline & B & beta & B & Beta \\
\hline \multicolumn{5}{|l|}{ Control variables: } \\
\hline Male & .02 & $(.02)$ & $.10 *$ & $(.10)$ \\
\hline Married & .07 & $(.06)$ & -.02 & $(-.02)$ \\
\hline Church attendance (attends) & $.28 * *$ & $(.20)$ & -.04 & $(-.03)$ \\
\hline Age (years) & .01 & $(.09)$ & $.01 *$ & $(.13)$ \\
\hline \multicolumn{5}{|l|}{ Education: } \\
\hline Tertiary $^{\mathrm{a}}$ & --- & --- & --- & --- \\
\hline Secondary & .05 & $(.05)$ & .10 & $(.10)$ \\
\hline No qualification & $.19 * *$ & $(.16)$ & $.24 * *$ & $(.21)$ \\
\hline DUP/Sinn Fein supporter & .05 & $(.05)$ & -.01 & $(-.01)$ \\
\hline $\begin{array}{l}\text { Ethnonationalism: } \\
\text { Congruency in identity }\end{array}$ & $.12 * *$ & $(.12)$ & .05 & $(.05)$ \\
\hline Constant & .103 & & .035 & \\
\hline R-squared & .126 & & .078 & \\
\hline$(\mathrm{N})^{1}$ & $(439)$ & & $(464)$ & \\
\hline
\end{tabular}

Notes: Attitudes about teaching gay rights in schools are coded 0 (yes) and 1 (no); *, significant at the 0.05 level; **, significant at the 0.01 level; ${ }^{\text {a }}$, missing category of comparison; Alternative analysis based on a logistic regression model gave rise to identical substantive conclusions.

Source: Northern Ireland Life and Times Survey, 2012. 
Table 5: Congruency in Identity and Attitudes Towards Same-Sex Issues Among Protestants

\begin{tabular}{lcc}
\hline & \multicolumn{2}{c}{ (Percentages) } \\
& Congruent & Non-Congruent \\
\hline Contact with a gay or lesbian: & & \\
No & 42.1 & 26.9 \\
Yes & 57.9 & 73.1 \\
(N) & $(190)$ & $(253)$ \\
& & \\
Source of Sexual Orientation: & 36.8 & 27.8 \\
Matter of choice & 63.2 & 72.2 \\
Born that way & $(171)$ & $(237)$ \\
(N) & & \\
& & \\
Equality for Gays or lesbians: & 23.0 & 13.0 \\
Changes definitely gone too far & 40.3 & 31.8 \\
Changes probably gone too far & 26.7 & 36.4 \\
More should probably be done & 9.9 & 18.8 \\
More should be definitely done & $(191)$ & $(239)$ \\
(N) & & \\
\hline
\end{tabular}

The question was: 'Which of these two statements comes closest to your own view? Lesbians and gay men are born that way and their sexual orientation is not something that can be changed or Lesbians and gay men choose their sexual orientation they can change it if they want to'; Do you personally know anyone who is gay or lesbian?; Some people think that people who are gay or lesbian are still not treated equally in our society, while others think that efforts to make things equal has gone too far. What is your opinion?'

Source: Northern Ireland Life and Times Survey, 2012. 
Table 6: Effect of Ethnonationalism and Same-Sex Issues on Attitudes Towards Same-Sex Marriage Among Protestants

\begin{tabular}{|c|c|c|c|c|c|c|}
\hline & \multicolumn{6}{|c|}{ (Regression Coefficients: OLS) } \\
\hline & \multicolumn{2}{|c|}{ Model 1} & \multicolumn{2}{|c|}{ Model 2} & \multicolumn{2}{|c|}{ Model 3} \\
\hline & $\mathrm{b}$ & beta & $\mathrm{b}$ & beta & $\mathrm{b}$ & beta \\
\hline \multicolumn{7}{|l|}{ Control variables: } \\
\hline Male & - & - & $.17 * *$ & $(.17)$ & $.14^{* *}$ & $(.14)$ \\
\hline Married & - & - & -.01 & $(-.01)$ & -.02 & $(-.02)$ \\
\hline Church attendance (attends) & - & - & $.41 * *$ & $(.30)$ & $.23 * *$ & $(.17)$ \\
\hline Age (years) & - & - & $.01 * *$ & $(.16)$ & $.01 *$ & $(.11)$ \\
\hline \multicolumn{7}{|l|}{ Education: } \\
\hline Tertiary $^{\mathrm{a}}$ & - & - & - & - & - & - \\
\hline Secondary & - & - & .05 & $(.05)$ & -.01 & $(-.01)$ \\
\hline No qualification & - & - & .08 & $(.07)$ & -.03 & $(-.03)$ \\
\hline DUP supporter & - & - & .07 & $(.07)$ & -.01 & $(-.01)$ \\
\hline \multicolumn{7}{|l|}{ Ethnonationalism: } \\
\hline Congruency in identity & $.20 * *$ & $(.20)$ & $.14^{* *}$ & $(.14)$ & .09 & $(.08)$ \\
\hline \multicolumn{7}{|l|}{ Same-Sex issues: } \\
\hline Contact with gay/lesbians (no) & - & - & - & - & .01 & $(.01)$ \\
\hline Source of orientation (choice) & - & - & - & - & $.17 * *$ & $(.16)$ \\
\hline Equality for gay/lesbians (too far) & - & - & - & - & $.63^{* *}$ & $(.40)$ \\
\hline Constant & $.407 * *$ & & -.118 & & $-.227 * *$ & \\
\hline R-squared & .039 & & .196 & & .394 & \\
\hline$(\mathrm{N})$ & $(410)$ & & $(410)$ & & $(410)$ & \\
\hline
\end{tabular}

Notes: Attitudes towards same-sex marriages are coded 0 (valid) and 1 (invalid); *, significant at the 0.05 level; **, significant at the 0.01 level; ${ }^{\text {a }}$, missing category of comparison; Alternative analysis based on a logistic regression model gave rise to identical substantive conclusions.

Source: Northern Ireland Life and Times Survey, 2012. 
Table 7: Effect of Ethnonationalism and Same-Sex Issues on Teaching About Equality for Gay and Lesbians in Schools among Protestants

\begin{tabular}{|c|c|c|c|c|c|c|}
\hline & \multicolumn{6}{|c|}{ (Regression Coefficients: OLS) } \\
\hline & \multicolumn{2}{|c|}{ Model 1} & \multicolumn{2}{|c|}{ Model 2} & \multicolumn{2}{|c|}{ Model 3} \\
\hline & $\mathrm{b}$ & beta & $\mathrm{b}$ & beta & $\mathrm{b}$ & beta \\
\hline \multicolumn{7}{|l|}{ Control variables: } \\
\hline Male & - & - & .02 & $(.02)$ & -.02 & $(-.02)$ \\
\hline Married & - & - & .07 & $(.06)$ & .05 & $(.05)$ \\
\hline Church attendance (attends) & - & - & $.28 * *$ & $(.20)$ & .10 & $(.08)$ \\
\hline Age (years) & - & - & .01 & $(.09)$ & .01 & $(.02)$ \\
\hline \multicolumn{7}{|l|}{ Education: } \\
\hline Tertiary $^{\mathrm{a}}$ & - & - & - & - & - & - \\
\hline Secondary & - & - & .05 & $(.05)$ & -.01 & $(-.01)$ \\
\hline No qualification & - & - & $.19 * *$ & $(.16)$ & .05 & $(.05)$ \\
\hline DUP supporter & - & - & .05 & $(.05)$ & -.03 & $(-.03)$ \\
\hline \multicolumn{7}{|l|}{ Ethnonationalism: } \\
\hline Congruency in identity & $.17 * *$ & $(.17)$ & $.12^{*}$ & $(.12)$ & .06 & $(.06)$ \\
\hline \multicolumn{7}{|l|}{ Same-Sex issues: } \\
\hline Contact with gay/lesbians (no) & - & - & - & - & .07 & $(.07)$ \\
\hline Source of orientation (choice) & - & - & - & - & .05 & $(.05)$ \\
\hline Equality for gay/lesbians (too far) & - & - & - & - & $.78 * *$ & $(.49)$ \\
\hline Constant & $.486^{* *}$ & & .103 & & -.008 & \\
\hline R-squared & .028 & & .126 & & .364 & \\
\hline$(\mathrm{N})$ & (410) & & $(410)$ & & $(410)$ & \\
\hline
\end{tabular}

Notes: Attitudes towards teaching about equality for gay and lesbian people are coded from 0 (more definitely needs to be done) to 1 (definitely gone too far); *, significant at the 0.05 level; **, significant at the 0.01 level; a , missing category of comparison; Alternative analysis based on a logistic regression model gave rise to identical substantive conclusions.

Source: Northern Ireland Life and Times Survey, 2012. 